\title{
WEB BASED APPLICATION FOR EARLY DETECTION OF VITAMIN AND MINERAL DEFICIENCY
}

\author{
Nina Sevani ${ }^{1}$ and Yosua Jaya Chandra \\ Department of Information Technology, Faculty of Engineering and Computer Science \\ Krida Wacana Christian University, Jakarta 11470, Indonesia \\ Email: ${ }^{1}$ nina.sevani@ukrida.ac.id
}

\begin{abstract}
The deficiency of vitamin and mineral or general micronutrients may lower human productivity. In general, the lack of public understanding of the micronutrients, the limited number of the nutritionists, the time and the cost are the reasons for people reluctant to meet nutritionist. The use of web-based computer application can be implemented to overcome the difficulty. Using the application, the user can detect and check their micronutrient conditions independently. The user can submit their physical conditions by responding to the given questions from the application. The provided data will be analysed using the forward chaining inference method to determine the kind of required nutrients. Finally, the application's outputs are the possible type of the nutrient deficiency and its chance. The evaluation of the developed application indicates that the error rate is very small in the order about $2 \%$ and the majority of the system users and subject matter experts were satisfied with its performance.
\end{abstract}

Keywords: Certainty Factors; Deficiency; Forward Chaining; Mineral; Vitamin

\section{INTRODUCTION}

Micronutrients like vitamin and mineral serve as antioxidant to strengthen body's immune system [1]. The deficiency of micronutrient may cause physical disorders and at the end, it also interferes productivity and the growth of the brain cells $[2,3]$. The children at school-age need micronutrient to improve their intelligence and academic performance. Furthermore, it is better if they get various micronutrients intake [4]. The weakness of body's immune system because of the micronutrient deficiency can also make the body prone to infection [5].

There are many ways to prevent micronutrient deficiency from the primary to the secondary prevention. The primary prevention can be done by maintaining the healthy lifestyle and diet. The secondary prevention

Received: June 17, 2016; received in revised form: June 24, 2016; accepted: July 8, 2016; available online: August 19, 2016. is by doing early detection of the possibility of the disease and health problem with a regular medical check-up [6].

The micronutrient deficiency should be detected as early as possible to minimise its harmful effects. The early detection can be done by observing changes in some body areas like the tongue [7], getting a consultation with a medical specialist, and conducting a blood test in the laboratory [8]. However, limitations such as the medical cost and distance may prevent one to perform those early detection procedures. In the developing countries where the medical facilities are limited, we often witness patients have to follow through a long queue [9]. The awareness of the early detection is often limited. The cost is the main reason to avoid taking the blood test.

The use of the technology like computer application for early detection of body condition may offer help to overcome the above problems [10]. In particular, the use of web-based application can provide the results of the detection within a short amount of time. In addition, the application is practicaly because it can be accessed from anywhere at anytime. Survey conducted by MarkPlus Insight showed that the Internet users in Indonesia has reached the number of 61 Million people with access duration more than three hour each time of the use [11]. Therefore, the computer application is essential for the community to provide, at least, an early step to prevent disease and to get further recommendations [12].

According to many works, the certainty factor is important. It accommodates in incompleteness and uncertainty in the process of identifying symptoms [1214]. It also describes the possibility of the disease [15] and allows the user to input their level of belief [9]. With it, the user can choose the answer beside 'Yes' and 'No'. More symptoms can be integrated with the 
Cite this article as: N Sevani and Y J Chandra, "Web based application for early detection of vitamin and mineral deficiency”, CommIT (Communication \& Information Technology) Journal 10(1), 53-58, 2016.

use of the factor [9]. The certainty factor has been used to detect disease in human and animal, for example, to detect children's disease [12], internal disease [9], disease in dog [14], and the cow skin disease [15]. It was used to diagnose maternal disease [11] and diabetes nephropathy disease [13] where the process involved six primary variables: diabetes mellitus history, hypertension history, large blood vessel abnormalities, abnormalities of the small blood vessel, protein in the blood, and glomerular filtration rate. It is deemed appropriate to measure the uncertainty in the detection results.

The previous studies have shown that there were some computer applications to detect micronutrient deficiency and its probability of occurence or certainy factor [16]. The detection can be done on a conventional rule-based method $[17,18]$. The certainty factor provides an indication on the possibility of the micronutrient deficiency [13]. The factors allow us to take into account the vagueness in our belief or opinion.

The goal of this research is to develop a webbased application for early detection of micronutrient deficiency by taking into account the uncertainty factor. Using the forward chaining inference, the application begins by asking symptoms to the user and ends by providing the information regarding the kind of micronutrient deficiency and the related uncertainty factor. The application is designed to detect deficiency of fat-soluble vitamin (vitamin A, D, E, and K), water-soluble vitamin (vitamin B and C), and micromineral deficiency (Iron, Zinc, Iodium, and Fluor). The application is designed based on web such that the user can access easily the system. The application will also be facilitted with the users medical records for them to track their health history. In addition, the results will also be complemented with explanation to increase the user's knowledge and awareness about the importance of the micronutrient intake. This information is also essential for medical practitioners.

\section{RESEARCH METHOD}

The research procedure is shown in Fig. 1. It begins with the knowledge acquisition process involving mainly literature review and interviewing subject matter experts. The next process is the knowledge representation and application design. A use case diagram will be used in the process. The last process is the testing and evaluation processes involving the users, the subject matter experts, and the application developer.

\section{A. Knowledge Acquisition}

The knowledge acquisition is the process to collect, transfer, and transform knowledge from experts to a computer problem [19]. In this research, the knowledge is acquired from written sources like books, journals, and articles related to micronutrients, and tacit knowledge from the subject matter experts, like the nutritionists.

The results of the knowledge acquisition process are the causative factor of the micronutrient deficiency, prevention, and procedure to detect the possibility of the micronutrient deficiency. The knowledge acquisition also provides all the symptoms, their weights and effects. All the acquired knowledge will be stored in a knowledge base.

\section{B. Inference Method}

This developed application uses the forward chaining inference method. The user should be questioned for the answers related to their physical condition and the weight of their answers. All the answer will be matched to the knowledge in the knowledge base including calculating the certainty factors. The results are the kind of the micronutrient deficiency, the certainty of the result, and the solutions for the deficiency. The inference method is shown in Fig. 2.

\section{Use Case Diagram}

The use case diagram is a UML diagram used to describe the interaction or correlation between the user with the system including the user's action in the system. The application has two level of the users: member $s$ and guests. They are distinguished in the access rights. The interaction between the member and the guest can be seen in Fig. 3.

\section{Certainty Factor Calculation Algorithm}

The certainty factor $(\mathrm{CF})$ is a parameter that shows the value of the belief and is expressed as [19]:

$$
\mathrm{CF}(\mathrm{H}, \mathrm{E})=\mathrm{MB}(\mathrm{H}, \mathrm{E})-\mathrm{MD}(\mathrm{H}, \mathrm{E}),
$$

where $\mathrm{CF}$ denotes the certainty factor, $\mathrm{H}$ is the hypothesis, $\mathrm{E}$ is the evidence, $\mathrm{MB}$ is the measure of the increased belief, and MD is the measured of the increased disbelief. The variable $\mathrm{CF}(\mathrm{H}, \mathrm{E})$ is the certainty factor regarding the $\mathrm{H}$ hypothesis and is influenced by the $\mathrm{E}$ evidence. The variable takes a value within the range of -1 and +1 . The value of -1 means a complete disbelief state and the value of +1 means a complete belief state. The variable $\mathrm{MB}(\mathrm{H}, \mathrm{E})$ denotes the level of the increasing belief to the $\mathrm{H}$ hypothesis influenced by the E evidence. The variable 
Cite this article as: N Sevani and Y J Chandra, "Web based application for early detection of vitamin and mineral deficiency", CommIT (Communication \& Information Technology) Journal 10(1), 53-58, 2016.

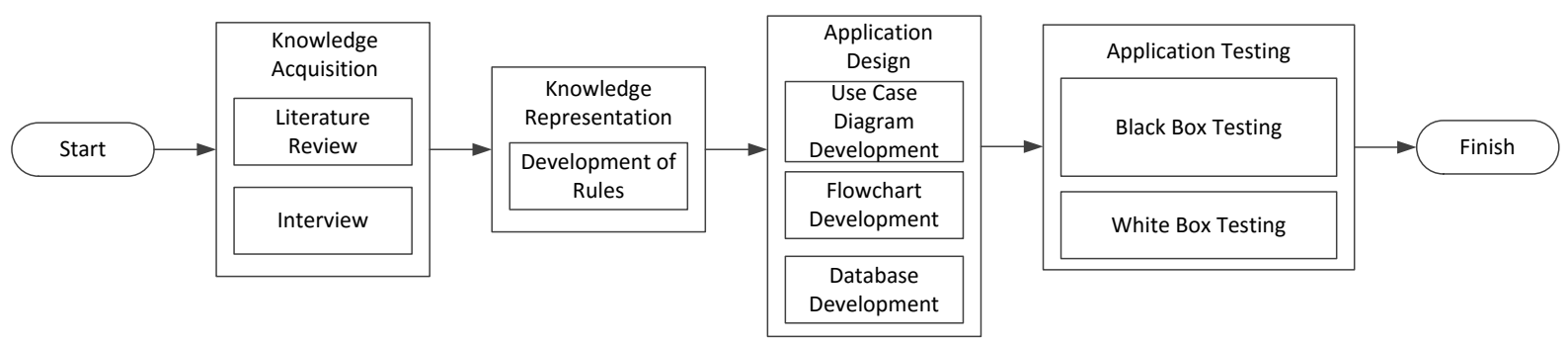

Fig. 1. The current research procedure.

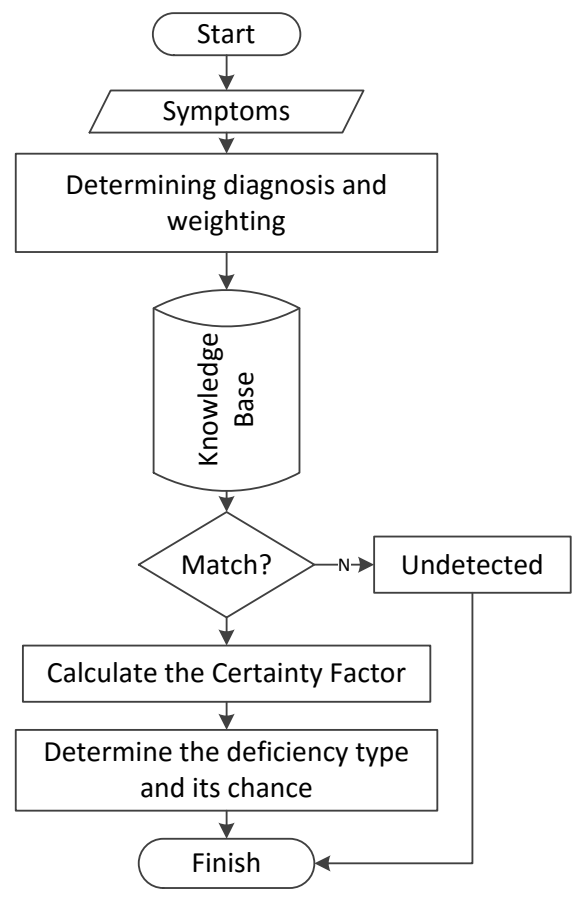

Fig. 2. The procedure of the inference method of the micronutrient deficiency.

$\mathrm{MD}(\mathrm{H}, \mathrm{E})$ means the level of the increasing disbelief to the $\mathrm{H}$ hypothesis influenced by the $\mathrm{E}$ evidence.

\section{E. Application Testing}

This application will be tested using the black box testing method conducted by the users and subject experts. The aim of this testing is to find out whether the application output is in line with the expectation. The application will also be tested using the white box testing to test the system flow.

\section{RESULTS AND DISCUSSION}

\section{A. Knowledge Representation}

The acquired knowledge is represented in the form of rules that contain symptoms and weight. In total,

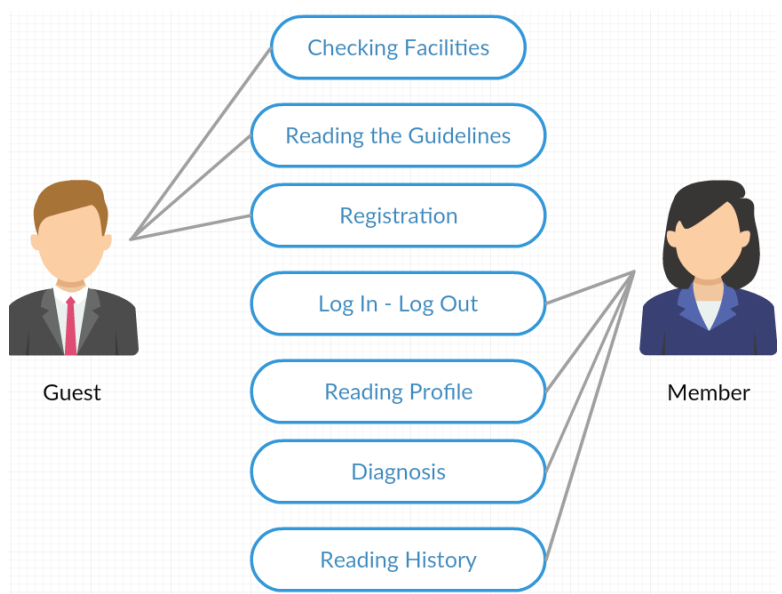

Fig. 3. The Use Case Diagram.

there are 49 rules. The following is the example of the rules with the weight:

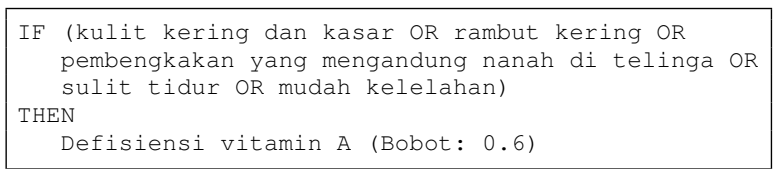

\section{B. Implementation}

Figures 4-6 show three example pages from the developed web-based application. All the webpages are using the same template containing application menus that can be selected by user. In total, there are seven application menus: "Beranda" to return to the home page, "Fasilitas Penjelas" to go to the facility explanation page, "Petunjuk" to go to the explation menu of how to use the application, "Diagnosa" to go to the diagnose microvitamin deficiency page, "Tentang" to go to the about page, "Logout" to leave the system, and finally, "Profil" to go to the user's information and diagnosis history page of the user.

Figure 4 presents the "Diagnosa" page, which contains the questions that need to be responded by the user. Figure 5 presents the page that asks the user to 
Cite this article as: N Sevani and Y J Chandra, "Web based application for early detection of vitamin and mineral deficiency”, CommIT (Communication \& Information Technology) Journal 10(1), 53-58, 2016.

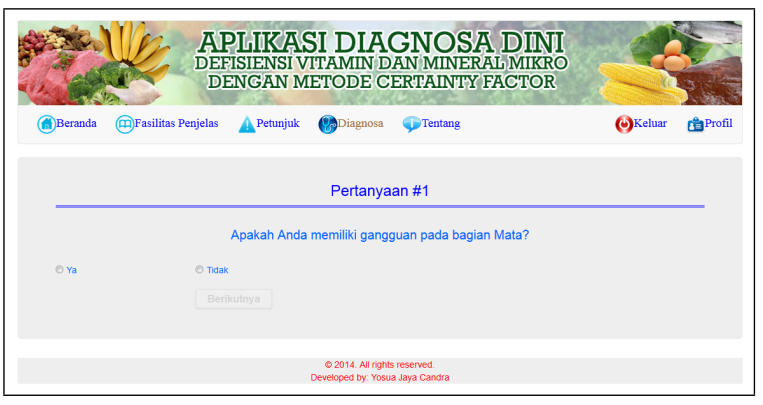

Fig. 4. The Diagnose Menu.

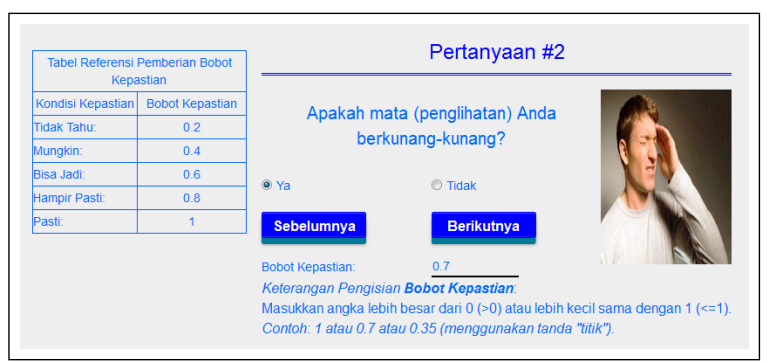

Fig. 5. The Page for the Weighting Factors.

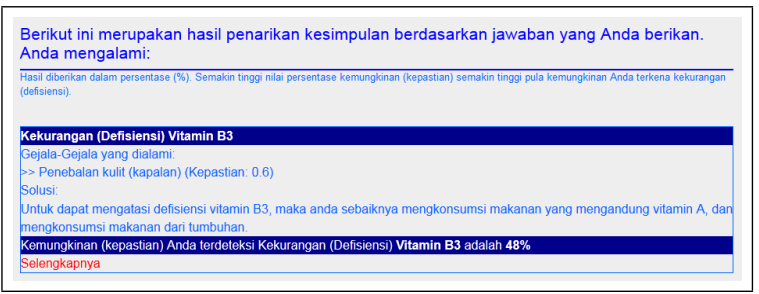

Fig. 6. The Page for Showing the Diagnose Results.

enter the weighting factor of the symptoms. Only those users who selected "Yes" to the question that need to provide the weighting factor. The weighting factor reflects the level of confidence for the symptoms in the user's perspective. The user who responded "No" will directly be directed to the next question. Finally, Fig. 6 presents the result page where the user can obtain the results of the diagnosis including their confidence levels.

\section{Black Box Testing}

The black box testing is conducted by the users and experts through questionnaire to study the acceptance rate of the application and level of certainty of the application's result. The black box testing is a common test method to test specification of a software and its functions. The black box testing does not need any knowledge regarding computer programs neither the understanding the internal works of the application [20].
The black box testing is implemented by distributing questionnaires to 50 users. The questions cover the aspects of the user interface of the application, the ease of use of the application, and the functions and benefits of the application. Generally, most of the users suggest that they can easily use the application and strongly believe that the application would be beneficial for them and for the community. Recapitulation of the questionnaire result can be seen in Table I.

In addition, the black box testing is also conducted by 50 experts. The opinions of those experts are then compared to the results provided by the application. This comparison reveals that the web-based application has a small error rate of $2 \%$.

\section{White Box Testing}

The objective of the white box test is to verify that the software has been developed correctly from the internal perspective including the workflow of the program [21]. The system should show a logical flow from every structure and functions in the application. The testing is conducted to all the system logical flows and the results indicate that every system flow goes well according to the expectation.

\section{CONCLUSIONS}

The current study discusses the development of a web-based application for early detection of vitamin and mineral deficiency. It is importance by considering that the deficiency may severely affect the body's immune system and preventing the growth of brain cells. The current life style and diet are also additional factors for the importance of the application. The application is much more important in the developing countries where the medical infrastructures and facilities are minimum. The web-based application is developed to help medical practitioner to facilitate early health evaluation. The system relies on the available rich preexisting knowledge regarding the deficiency and encodes the knowledge in a number of rule-based recommendation strategy. The features offerred by the application are: it helps to diagnose the micronutrient deficiency through physical symptoms, it is equipped with the explanation facility that can be one of information source about micronutrient, it takes into account the uncertainty factor to process the symptoms; thus, allowing the application to provide the information of the certainty level of the result to facilitate the decision making process, and finally, it allows the users to monitor their health history and observe their condition through the medical records. 
Cite this article as: N Sevani and Y J Chandra, "Web based application for early detection of vitamin and mineral deficiency", CommIT (Communication \& Information Technology) Journal 10(1), 53-58, 2016.

TABLE I

The Results of The Black Box Testing: Recapitulation of the Responses from the Users Regarding the Web-Based application. The Value with the Bracket is in Percent.

\begin{tabular}{|c|c|c|c|}
\hline \multirow{2}{*}{ No. } & \multirow{2}{*}{ Question } & \multicolumn{2}{|c|}{ Response } \\
\hline & & Yes & No \\
\hline 1 & Pengetahuan awal pengguna akan defisiensi zat gizi mikro & $17(34)$ & $33(66)$ \\
\hline 2 & Ketersediaan informasi akan zat gizi mikro & $46(92)$ & $4(8)$ \\
\hline 3 & Kemudahan penggunaan setiap fitur dalam aplikasi & $43(86)$ & $7(14)$ \\
\hline 4 & $\begin{array}{l}\text { Kemudahaan untuk mengerti isi aplikasi (dilihat dari sisi penjelasan, saran, hingga } \\
\text { pertanyaan yang ditampilkan) }\end{array}$ & $46(92)$ & $4(8)$ \\
\hline 5 & $\begin{array}{l}\text { Pendapat pengguna bahwa kemampuan aplikasi untuk membantu melakukan deteksi } \\
\text { dini sudah cukup memadai. }\end{array}$ & $42(84)$ & $8(16)$ \\
\hline 6 & Pendapat pengguna bahwa tampilan aplikasi mudah dipahami dan menarik. & $40(80)$ & $10(20)$ \\
\hline 7 & $\begin{array}{l}\text { Pendapat pengguna bahwa aplikasi dapat membantu untuk mencegah dan mem- } \\
\text { perkecil kemungkinan terkena defisiensi }\end{array}$ & $43(86)$ & $7(14)$ \\
\hline 8 & $\begin{array}{l}\text { Pendapat pengguna bahwa aplikasi dapat memotivasi individu untuk lebih memper- } \\
\text { hatikan kesehatan }\end{array}$ & $41(82)$ & $9(18)$ \\
\hline 9 & $\begin{array}{l}\text { Pendapat pengguna bahwa kehadiran aplikasi dapat mendorong peningkatan ke- } \\
\text { hidupan kesehatan masyarakat Indonesia. }\end{array}$ & $46(92)$ & $4(8)$ \\
\hline 10 & $\begin{array}{l}\text { Pendapat pengguna bahwa kehadiran aplikasi bermanfaat bagi masyarakat Indone- } \\
\text { sia untuk menangani dan mengetahui defisiensi zat gizi mikro secara dini. }\end{array}$ & $47(94)$ & $3(6)$ \\
\hline 11 & Pendapat pengguna akan perlunya pengembangan lebih lanjut terhadap aplikasi ini. & $46(92)$ & $4(8)$ \\
\hline
\end{tabular}

\section{REFERENCES}

[1] F. Ernawati et al., "Peran beberapa zat gizi mikro dalam sistem imunitas," Gizi Indonesia, vol. 36, no. 1, 2013.

[2] D. Krisnansari, "Nutrisi dan gizi buruk," Mandala of Health, vol. 4, no. 1, pp. 60-68, 2010.

[3] S. Almatsier, Prinsip Dasar Ilmu Gizi. Jakarta, Indonesia: Gramedia, 2009.

[4] A. Eilander, T. Gera, H. S. Sachdev, C. Transler, H. C. van der Knaap, F. J. Kok, and S. J. Osendarp, "Multiple micronutrient supplementation for improving cognitive performance in children: systematic review of randomized controlled trials," The American journal of clinical nutrition, pp. ajcn-28 376, 2009.

[5] Vitamin. (2016, August) Sumber pengetahuan sehat. [Online]. Available: http://kb.123sehat. com/

[6] PAPDI. (2016, August) Perhimpunan dokter spesialis penyakit dalam indonesia. PB-PAPDI. [Online]. Available: http://www.pbpapdi.org/ papdi.php?pb=home

[7] Detik. (2016, August) detikhealth. [Online]. Available: http://health.detik.com/

[8] Kompas. (2016, August) Health: Kompas. [Online]. Available: http://health.kompas.com/

[9] T. A. Munandar, Suherman, and Sumiati, "The use of certainty factor with multiple rules for diagnosing internal disease," International Journal of Application or Innovation in Engineering \& Management, vol. 1, no. 1, pp. 58-64, September 2012.

[10] A. Oguntimilehin, A. Adetunmbi, K. Olatunji et al., "A machine learning based clinical decision support system for diagnosis and treatment of typhoid fever," A Machine Learning Based Clinical Decision Support System for Diagnosis and Treatment of Typhoid Fever, vol. 4, no. 6, pp. 961-969, 2014.

[11] M. W. Pangestika, B. Irawan, and Y. Brianorman, "Sistem pakar untuk diagnosa penyakit ibu hamil berbasis mobile," e-Indonesia Initiatives (eII Forum), Institut Teknologi Bandung, Tech. Rep., May 2013.

[12] R. A. Hustinawaty, "The development of web based expert system for diagnosing children disease using php and mysql," International Journal of Computer Trends and Technology, vol. 10, no. 4, pp. 197-202, April 2014.

[13] D. Puspitasari, E. Martiana, and Y. Setiowati. (2010, April) Sistem pakar diagnosa diabetes nefropathy dengan metode certainty factor berbasis web dan mobile. Online. Politeknik Elektronika Negeri Surabaya. Surabaya, Indonesia. [Online]. Available: http://repo.pens.ac.id/607/ 
Cite this article as: N Sevani and Y J Chandra, "Web based application for early detection of vitamin and mineral deficiency”, CommIT (Communication \& Information Technology) Journal 10(1), 53-58, 2016.

[14] E. Setyarini, D. Putra, and A. Purnawan, "The analysis of comparison of expert system of diagnosing dog disease by certainty factor method and dempster-shafer method," International Journal of Computer Science Issues (IJCSI), vol. 10, no. 2, pp. 576-584, January 2013.

[15] S. Ahmad, M. Mustafid et al., "Sistem pakar diagnosa awal penyakit kulit sapi berbasis web dengan menggunakan metode certainty factor," Ph.D. dissertation, Universitas Diponegoro, 2012.

[16] A. Labellapansa and A. T. Boyz, "Sistem pakar diagnosa dini defisiensi vitamin dan mineral," Jurnal Informatika, vol. 10, no. 1, pp. 1156-1163, January 2016.

[17] N. Sevani and M. Joshua, "Implementasi forward chaining untuk diagnosa defisiensi vitamin larut dalam lemak berbasiskan web," Jurnal Teknologi
Komputer dan Informatika, vol. 10, no. 2, pp. 5159, 2014.

[18] N. Sevani and R. Unwaru, "Aplikasi deteksi dini defisiensi mineral mikro pada manusia berbasis web," Indonesian Journal of Computing and Cybernatics Systems, vol. 8, no. 2, pp. 213-222, July 2014.

[19] Kusrini, Sistem Pakar Teori dan Aplikasi. Yogyakarta: Amikom, 2006.

[20] S. H. Trivedi, "Software testing techniques," International Journal of Advanced Research in Computer Science and Software Engineering, vol. 2, no. 10, 2010.

[21] M. G. Limaye, Software Testing: Principles, Techniques, and Tools. New Delhi: Tata McGraw-Hill Education Private Limited, 2009. 